\title{
SIJAISHUOLTO OSANA ELÄMÄNTARINAA - ELÄMÄN- KULUN KÄÄNNEKOHTIEN ANALYYSI SIJAISHUOLLOSTA AIKUISTUNEIDEN KOKEMUKSISTA
}

\author{
Katarina Groop: VTM, sosiaalityön jatko-opiskelija, Tampereen yliopisto
}

katarina.groop@tuni.fi

Janus vol. 29 (3) 2021, 249-266

\section{o a I U \&}

Tiivistelmä
VERTAISARVIOITU
KOLLEGIALT GRANSKAD KOLLEGIALT GRANSHAD
PEER-REVIEWED
WWN.

Artikkelissa tarkastellaan merkittäviä elämänkulun käännekohtia (turning points) lastensuojelun sijaishuollosta aikuistuneiden kokemuksissa.Viitekehyksenä on käännekohtien teoreettinen tarkastelu, jota avataan elämänkulullisesta tutkimuksesta käsin. Artikkelin aineisto koostuu sijaishuollosta aikuistuneille järjestetyistä fokusryhmätyöpajoista $(n=20)$, teemahaastatteluista $(n=3)$ ja kirjoitetuista tarinoista $(n=3)$. Käännekohtien merkitys sijaishuollossa kasvaneiden kertomuksissa linkittyi ihmisja perhesuhteiden, työ- ja opiskeluelämän sekä sosiaalisten ympäristöjen muutoskohtiin. Tulosten perusteella elämän käännekohdiksi määrittyivät huostaanotto ja sijaishuoltoaika, itsenäistyminen, omillaan oleminen ja vanhemmaksi tuleminen. Lastensuojelujärjestelmä toi käännekohtiin institutionaalisesti määrittyviä rakenteita ja ikärajakeskeisiä käytänteitä. Merkittäviä käännekohtia sävyttivät niin negatiiviset kuin positiiviset, kannattelevat ulottuvuudet.

\section{JOHDANTO}

Lastensuojelututkimuksen kentällä on peräänkuulutettu aikuisuuden elämänvaiheeseen kytkeytyvän tutkimustiedon tärkeyttä, jotta ymmärrys sijaishuollossa kasvamisen elämänkulullisista vaikutuksista syventyisi (Murray \& Goddard 2014). Yhtenä vastauksena on esitetty elämänkulullisen viitekehyksen soveltamista sijaishuoltokokemusten tutkimisessa. Elämänkulullinen viitekehys tarjoaa mahdollisuuden tarkastella monimuotoisia prosesseja, muutosta ja ihmissuhteisiin sekä institutionaalisiin toimintoihin liittyviä tekijöitä, jotka vaikuttavat lastensuojelun piirissä kasvaneiden elämänkulkuun (White \& Wu 2014).
Elämänkulkua koskevassa kirjallisuudessa käsitellään elämän käännekohtia (turning points) ja niiden roolia muutosta käynnistävänä voimana. Käännekohta märittyy tapahtumaksi, johon kytkeytyy merkittävä muutos, joka järjestää elämänkulkua uudella tavalla. (Hutchison 2005.) Michael Rutterin (1996) mukaan elämänkulun käännekohtiin liittyy kokemuksen yksilöllinen luonne. Käännekohdat voivat merkityksellistyä yksilön elämänkulkua ravisteleviksi, negatiivisiksi tapahtumiksi (mm. menetykset, parisuhteen katkeaminen, sairastuminen) tai uudenlaista merkitystä luoviksi, positiivisiksi tapahtumiksi (mm. tutkinnon saavuttaminen, lapsen syntymä) (Wethington 2002; Enz \& Talarico 2016). Positiivisen ja negatiivisen kokemuksen sävyero 
ei ole kuitenkaan mustavalkoinen, vaan negatiivinen tapahtuma (esim. lapsen huostaanotto) voi käynnistää positiiviseksi koetun käännekohdan (esim. päihteiden käytön lopettaminen).

Tarkastelen artikkelissa elämänkulun käännekohtia sijaishuollossa kasvaneiden kokemuksissa. Lastensuojelu ja sijaishuoltoon sijoittaminen interventiona näyttäytyvät lapsen ja nuoren elämässä käännekohtana, joka sisältää useita muutoksia muun muassa lapsen ja perheen elinympäristöissä ja perhesuhteissa (White \& Wu 2014, 149). Kiinnostuksen kohteena on tarkastella, minkälaisia käännekohtia sijaishuollossa kasvaneet nimeävät ja minkälaisia kannattelevia tekijöitä tai taakkatekijöitä niihin kytkeytyy. Lähestyn elämänkulun käännekohtien analyysia narratiivisesta näkökulmasta, jossa ihmisen ajattelun, kokemuksen ja toiminnan nähdään kietoutuvan tarinoiden kertomiseen ja kuulemiseen (mm. Hänninen 1999). Aineistona ovat Ylitse-projektin ${ }^{1}$ toiminnassa järjestetyt fokusryhmätyöpajat $(n=20)$, teemahaastattelut $(n=3)$ ja kirjoitetut tarinat $(n=3)$.

\section{KÄÄNNEKOHTIEN MERKITYS ELÄMÄNKULUSSA}

Elämänkulullinen viitekehys tarkastelee tapoja ja merkityksiä, joilla kronologinen ikä, elämän käännekohdat, ihmissuhteet ja sosiaaliset muutokset muovaavat yksilön elämänpolkua syntymästä kuolemaan. Elämänkulun tutkimuksissa kiinnostusta ovat herättäneet erityisesti perhesuhteiden merkitys ja ylisukupolvinen sidostuneisuus. Viitekehykseen linkittyvät myös makrotason ulottuvuudet, kuten po- liittinen, taloudellinen ja kulttuurinen konteksti, joiden nähdään vaikuttavan ihmisen elämänkulkuun. (Elder 1994; Hutchison 2005.)

Käännekohdat ja niiden jäsentämisen tärkeys kytkeytyvät olennaisesti sosiaalityön kenttään, sillä sosiaalityön ja siihen liittyvien interventioiden kautta pyritään saavuttamaan ja tukemaan muutosta yksilön tai perheen elämässä (Hutchison 2005). Käännekohtien merkitystä elämänkulussa on tarkasteltu muun muassa avioeron (Montemurro 2014), päihteiden käytön (Teruya \& Hser 2010), rikollisuuden (Melde \& Esbensen 2011; Corman ym. 2011), maahanmuuton (Petroff 2016; Vesely ym. 2014), aikuisuuteen siirtymisen (Shanahan 2000; Rönka ym. 2003), vanhemmuuden (Zimbrick-Rogers ym. 2017; Dun 2010) ja läheisen menettämisen (Manoogian ym. 2018) näkökulmista. Lastensuojelun kontekstissa elämänkulullista ja käännekohtiin kytkeytyvää lähestymistapaa on sovellettu muun muassa lapsen kaltoinkohtelukokemusten vaikutusten tarkastelussa (Stewart ym. 2008; Hurren ym. 2017), sijoitettujen nuorten resilienssin tutkimisessa (Drapeau ym. 2007), sijaishuollosta itsenäistymisen jäsentämisessä (Höjer \& Sjöblom 2014) sekä sijaishuollosta aikuistuneiden opiskelukokemusten tutkimisessa (Brady \& Gilligan 2018).

Käännekohdan voivat käynnistää makrotason tapahtumat (luonnonkatastrofi, sota) tai yksilöä ja lähipiiriä koskettavat mikrotason tapahtumat (sairastuminen, ero, hyväksikäyttö). Mikrotason tapahtumiin lukeutuvat myös pienet tai yllättävät tapahtumat, jotka avaavat elämänpolulla uudenlaisia mahdollisuuksia tai käynnistävät sisäistä muutosta. Yksilön 
sisäinen merkityksenannon prosessi määrittää käännekohdan vaikutuksia (Reynolds \& Turner 2008). Käännekohdan voivat käynnistää normatiiviset tapahtumat, joiksi määritellään usein avioliitto, vanhemmuus, isovanhemmuus, koulun aloitus, eläköityminen ja vanhemman tai oman puolison kuolema.(Gilligan 2009,17-21.)Tutkimusten mukaan kyky sanoittaa käännekohdan merkityksellisyyttä linkittyy vahvasti psykologiseen hyvinvointiin (Tavernier \& Willoughby 2012; McLean \& Pratt 2006). Käännekohdat muovaavat käsitystä ihmisen toimijuudesta ja valinnanmahdollisuuksista (Juntunen 2020).

Suomalaisen aikuisväestön käännekohtia tutkineiden Anna Röngän, Sanna Oravalan ja Lea Pulkkisen (2003) mukaan käännekohtakokemukset liittyvät usein perheeseen, koulutukseen, työhön ja sosiaalisiin siirtymiin. Tutkimuksessa ilmeni toimijuuden ja valinnan merkitys: jos käännekohtaan kytkeytyy tunne henkilökohtaisesta valinnan mahdollisuudesta, koetaan se yleensä positiivisemmaksi (emt.). Sama tutkijaryhmä (Rönkä et al. 2002) tarkasteli käännekohtakokemuksia useita lapsuuden ja nuoruuden riskitekijöitä kohdanneiden aikuisten keskuudessa. Tulosten mukaan lapsuuden kokemukset heijastuvat siihen, miten käännekohtia koetaan ja käsitteellistetään aikuisuudessa. Nykyisellä elämäntilanteella on myös vaikutusta käännekohtien tarkastelussa. Lapsuuden riskitekijöistä huolimatta aikuisuudessa koettu hyvä elämänlaatu liittyi positiivisempien käännekohtien kuvaamiseen ja heikommaksi koettu nykyinen elämänlaatu puolestaan linkittyi negatiivissävytteisten käännekohtien kuvaamiseen. Käännekohtien määrittelyssä onkin vahvasti läsnä ajallinen ulottuvuus, sillä yksilö määrittelee käännekohdat retrospektiivisesti (Pillemer ym. 1998).

Robbie Gilligan (2009) tarkastelee käännekohtia pitkäkestoisen, positiivisen muutoksen käynnistävinä katalysaattoreina, jotka ovat avaimia kehityksellisten muutosten ymmärtämiseen. Gilligan mallintaa käännekohtaa neljän ulottuvuuden: tilaisuuden, valmiuden, toimijuuden ja kannattelevan kontekstin kautta. Ulottuvuuksien olemassaolo on välttämätöntä, jotta muutos tapahtuu. Tilaisuuden ulottuvuudessa valmius ja siihen kytkeytyvä ajoitus ovat merkityksellisessä roolissa. Toimijuus kytkeytyy olennaisesti käännekohtaan, sillä tilaisuuteen tarttuminen vaatii yksilöltä proaktiivista toimintaa. Kannatteleva konteksti viittaa elämässä läsnäoleviin, muutosta kannatteleviin elementteihin ja siihen, että yksilö kokee saavuttavansa edistymistä. Esimerkiksi työhön sitoutuminen tuottaa uralla etenemistä tai ahkera opiskelu avaa mahdollisuuksia jatko-opintoihin. Käännekohtien ulottuvuuksien ja mahdollisuuksien areenat eivät ole ajoitukseltaan jäykkiä, vaan ne voivat avautua myös myöhemmässä vaiheessa elämää. (Emt. 27-32.) Esimerkiksi jälkihuollossa oleva, koulun keskeyttänyt nuori voi löytää uuden innon opiskeluun ja hakeutua opintoihin myöhemmässä elämänvaiheessa.

Gilliganin tavoin käsitän käännekohdat muutosprosessin käynnistävinä tapahtumina. En tarkastele käännekohtia ainoastaan positiivisen muutoksen kautta, vaan otan tarkasteluun myös käännekohtien negatiiviset kokemukset. Käännekohtien analyysi tarjoaa kiinnostavan lähestymistavan sijaishuollossa kasva- 
neiden elämänkulun tarkasteluun: luoko sijaishuollossa kasvaminen joitakin erityisiä käännekohtakokemuksia samanlaisen kokemustaustan jakavien ihmisten elämänkulussa ja millä tavalla käännekohtien merkitystä ja ulottuvuuksia sanoitetaan?

\section{Tutkimusasetelma, Aineistot, MENETELMÄT JA ANALYYSI}

Aineisto koostuu Ylitse-projektin järjestämistä fokusryhmätyöpajoista $(n=20)$, haastatteluista $(n=3)$ ja kirjoitetuista kertomuksista $(\mathrm{n}=3)$. Aineisto on laajuudeltaan 72 litteroitua A4-sivua rivivälillä 1,5 .

\section{Fokusryhmätyöpajat}

Projektin toiminnassa järjestettiin vuosina 2016-2017 yhteensä 20 fokusryhmätyöpajaa sijaishuollosta aikuistuneille. Työpajoja järjestettiin viidessä eri kaupungissa ympäri Suomea. Osallistujien valintakriteerinä oli, että henkilöllä oli kokemus sijaishuollossa asumisesta ja itsenäistymisestä. Osallistujat rekrytoitiin SOS-Lapsikylän nykyisten ja eläköityneiden sijaisvanhempien sekä laitosmuotoisten sijaishuoltopaikkojen työntekijöiden kautta. Nämä yhteyshenkilöt jakoivat kohderyhmälle tiedon työpajojen sähköisestä ilmoittautumislinkistä. Osallistujien rekrytoiminen tapahtui myös lumipallomenettelyllä osallistujien pyytäessä tuttaviaan mukaan omista verkostoistaan. Ilmoittautuneille osallistujille lähetettiin kutsu -ja infokirje, jossa kerrottiin työpajan sisällöstä ja ryhmämuotoisesta elämänjanatyöskentelyn metodista. Infokirjeen kautta osallistujat viritettiin käännekohtien tarkasteluun ja ylisuku- polvisuuden tematiikkaan. Osallistujia pyydettiin pohtimaan etukäteen merkityksellisiä käännekohtia, niiden ajoitusta ja vaikutuksia omaan itseen ja elämänkulkuun. Osallistujia pyydettiin lisäksi pohtimaan ylisukupolvisuuteen liittyviä kysymyksiä, kuten oman lapsuuden, perhetaustan ja elämänkokemusten vaikutuksia omaan elämänkulkuun.

Fokusryhmämetodissa tietyn yhteisen nimittäjän omaava ryhmä keskittyy yhteisen teeman ympärillä käytävään keskusteluun. Metodiin sisältyy ajatus ryhmän kokoonpanon ja keskusteluteeman fokusoimisesta. Fokusryhmämenetelmän voi nähdä myös eräänlaisena ryhmähaastattelun muotona, vaikka keskustelu onkin vapaampaa eikä noudata haastattelulle tyypillistä kysymys-vastaus-kaavaa. (Stewart ym. 2007; Mäntyranta \& Kaila 2008.) Tässä tutkimuksessa yhteisenä nimittäjänä oli kokemus sijaishuollossa kasvamisesta.

Fokusryhmätyöpajojen osallistujamäärät vaihtelivat 2-9 henkilön välillä keston vaihdellessa kahdesta neljään tuntiin. Työpajoihin osallistuneita henkilöitä oli yhteensä 46 (32 naista, 14 miestä). Työpajoissa oli 70 osallistumiskertaa tarkoittaen sitä, että osa osallistui useampaan työpajakertaan. Useampia työpajatapaamisia järjestettiin paikkakunnilla, joissa osallistujat ilmaisivat toivetta tapaamisten jatkolle. Jatkotapaamisten osalta työpajoissa käsiteltiin osallistujien esiin tuomia käännekohtia syvemmällä otteella keskittyen tietyn käännekohdan tarkasteluun.

Osallistujista valtaosa oli asunut sijaisperheessä, mutta usealla oli kokemusta myös muista lastensuojelun sijaishuoltomuodoista (esim. vastaanottokoti, las- 
tenkoti, nuorisokoti). Osallistujien ikä vaihteli $17-50-$ vuoden välillä valtaosan ollessa iältään 25-30-vuotiaita nuoria aikuisia. Osa osallistujista tunsi toisensa entuudestaan oltuaan sijoitettuna samaan sijaishuoltopaikkaan. Osallistujista 37 prosentilla $(n=17)$ oli omia lapsia. Osallistujien elämässä lastensuojelun ylisukupolvisuuden ketjut olivat läsnä moninaisin tavoin; osan vanhemmat olivat eläneet lastenkodissa tai muuten rikkonaisessa perheympäristössä. Kuuden osallistujan kohdalla oman lapsen elämään linkittyi lastensuojelu erilaisin tavoin: osan kohdalla oma lapsi oli ollut jossain vaiheessa avohuollon sijoituksessa $(n=3)$, yhden lapsi oli huostaanotettu ja kahden vanhemman kohdalla oli tehty ennakollinen lastensuojeluilmoitus.

Työpajoissa käsiteltiin ryhmämuotoisen elämänjanatyöskentelyn avulla elämänkulun käännekohtia, niihin kytkeytyviä palvelutarpeita ja ihmissuhteiden merkitystä. Elämänjana on sosiaalityössä käytetty elämäkerrallinen työmenetelmä, jonka ydinajatuksena on käsitellä ihmisen elämänkulkua ja -tapahtumia sekä muistoja (Kekkonen 2004, 29-30). Menetelmää sovellettiin työpajoissa niin, että osallistujia pyydettiin pohtimaan ja keskustelemaan yhdessä merkitykselliseksi koetuista käännekohdista. Työpajoista rakentui varsin yksilöllisiä kokonaisuuksia. Osassa yhteisesti jaettuja kokemuksia koottiin seinälle ryhmän elämänjanaksi ja osassa painottui keskustelun ja kokemusten jaon merkitys. Työpajojen keskustelun virittäjinä, moderaattoreina, toimivat projektin kaksi työntekijää, joiden roolijako vaihteli sovitusti keskustelun kirjaajan ja vetäjän välillä.
Työpajojen alussa osallistujia informoitiin siitä, että työpajoista kirjataan muistiinpanoja, jota käytetään projektin toiminnan raportoinnissa, julkaisuissa ja koulutuksissa. Nauhoitettujen työpajakertojen aluksi osallistujilta pyydettiin lupa nauhoittamiseen, kerrottiin aineiston anonymisoinnista ja informoitiin aineiston käytöstä. Osallistujille painotettiin, että elämänkokemusten jakaminen on vapaaehtoista ja kukin voi itse päättää, miten haluaa niitä jakaa ryhmässä. Osallistujien yhteinen kokemus sijaishuollossa kasvamisesta loi ainutlaatuista pohjaa luottamuksellisen ilmapiirin syntymiselle ja toisten kertomusten kunnioittavalle kuulemiselle.

\section{Haastattelut ja tarinat aineistona}

Projektityöntekijät haastattelivat kolmea vanhempaa ensimmäisen lapsen saamisen elämänvaiheesta. Haastattelujen tarkoituksena oli syventyä kyseiseen käännekohtaan. Haastateltavat olivat osallistuneet työpajoihin. Haastattelut toteutettiin puhelinhaastatteluina vuonna 2017 ja niissä käsiteltiin kolmea teemaa: elämäntilannetta, palvelukokemuksia- ja tarpeita sekä tukiverkostojen roolia lapsen saamisen elämänvaiheessa. Puhelinhaastattelut nauhoitettiin haastateltavien luvalla. Haastattelujen kesto vaihteli 30 minuutista tuntiin.

Työpaja- ja haastatteluaineiston lisäksi aineistona on kolme tarinaa. Projektissa haluttiin tarjota sijaishuollosta aikuistuneille mahdollisuus jakaa oma tarinansa anonyymisti. Syksyllä 2017 Ylitse-projektin sosiaalisen median kanavassa julkaistiin kirjoituskutsu, jossa pyydettiin kertomaan sijaishuollon roolista ja vaikutuksista omassa elämänkulussa. Kir- 
joituskutsuun vastasi kolme henkilöä, joiden tarinat ovat osana aineistoa.

Tutkimusetiikka, aineiston rajoitukset ja analyysi

Tutkimuseettiset periaatteet on otettu huomioon tutkimusaineiston hankinnassa, säilyttämisessä ja tulosten esittämisessä. Sensitiivisten aiheiden, kuten henkilökohtaisten kokemusten ja vaikeiden perhesuhteiden tutkimuksessa korostuvat moninäkökulmainen eettinen pohdinta, itsemääräämisoikeus, vahingoittamattomuuden vaade ja yksityisyyden suojaaminen. Lisäksi tutkijalta vaaditaan erityistä herkkyyttä ja kykyä kohdata kipeitä kokemuksia. (Laitinen \& Uusitalo 2007; Pösö 2008; Hämäläinen ym. 2014.) Työpajoissa jaetut kokemukset olivat hyvin henkilökohtaisia ja tunnepitoisia vaihdellen surun, vihan, katkeruuden ja ilon välillä. Osallistujille annettiin projektityöntekijöiden yhteystiedot, jotta osallistujat voisivat ottaa yhteyttä, mikäli työpajakeskustelut jäävät vaivaamaan mieltä. Ryhmämuotoisen metodin positiivisiksi puoliksi muotoutuivat vertaistuen mahdollistuminen ja anonymiteetin suojaaminen. Tulososiossa päädyin olla käyttämättä valokuvia ryhmien luomista elämänjanoista, sillä niissä näkyi tunnistettavuuteen vaikuttavia paikkojen nimiä.

Aineistossa korostuvat ryhmässä jaetut kertomukset käännekohtakokemuksista. Ryhmäkeskustelulle on ominaista, että osallistujien jakamat tarinat jatkavat ja täydentävät toinen tosiaan (Valtonen 2005). Ryhmäkeskusteluissa painottuvat näin ollen yhteisesti jaetut ja nimetyt käännekohdat. Fokusryhmämetodin haasteina ovat ryhmän mielipiteiden yhdenmukaistuminen ja monimuotois- ten keskustelujen yksinkertaistaminen analyysissa (mm. Acocella 2012). Mielipiteiden ja kokemusten yhdenmukaistumisen tuomat rajoitukset on huomioitava aineiston osalta. Aineiston osalta on hyvä huomioida myös naispuolisten osallistujien enemmistö ja osallistujien ikäerot. Osallistujat olivat hyvin eri ikäisiä ja erilaisissa elämäntilanteissa olevia. Vanhemmilla osallistujilla sijaishuoltoon liittyvistä kokemuksista oli kulunut aikaa jo vuosikymmeniä, ja nuoremmat olivat itsenäistymisen kynnyksellä. Sijaishuollossa kasvamisen kokemukset rakentuvat erilaisiksi eri aikakausina. Käännekohtien merkitykset voivat todentua ja muuttua ajan myötä, kun ihminen pystyy arvioimaan pidempiaikaisten vaikutusten näkökulmia (Rutter 1996). Haastatteluissa keskityttiin vanhemmaksi tulemisen käännekohtaan, joka oli nostettu merkittäväksi kokemukseksi työpajojen yhteydessä. Tiettyyn käännekohtaan keskittyminen suuntasi haastatteluun osallistujien esiintuomia kokemuksia. Tarinoiden kohdalla on huomioitava se, että sosiaalisen median kautta jaettuun kirjoituskutsuun on voinut vastata kuka tahansa.

Yhdistän artikkelissa fokusryhmätyöpajojen, kirjoitettujen tarinoiden sekä haastattelujen aineistoja narratiivistemaattista analyysia hyödyntäen. Narratiivisessa perinteessä elämän nähdään rakentuvan kertomuksena, joka on alituisesti läsnä niin nykyisyydessä kuin eletyssä elämässä (Nousiainen 2016, 72). Aineiston analyysiprosessi alkoi jo fokusryhmätyöpajojen yhteydessä, sillä useassa työpajassa keskustelun ohessa luotiin ryhmän yhteistä elämänjanaa post it-lappuja hyödyntäen. Valmiit elämänjanat valokuvattiin aineiston analyysia ja koontia varten. Pääteemat 
lähtivät muotoutumaan jo aineiston hankintavaiheessa. Saturaatiota ja käännekohtien samanlaisia perusteemoja alkoi hahmottumaan aineistonkeruun puolivälissä. Nämä teemat ohjasivat analyysin jatkovaiheita. Litteroitujen työpajojen, haastattelujen sekä kirjoitettujen tarinoiden muodostaman aineiston analyysissa koodasin aineistossa esiintyneet merkittäväksi koetut elämänkulun käännekohdat ja asetin ne kronologiseen järjestykseen. Analyysin edetessä pilkoin ja ryhmittelin aineistoa etsien tiettyä teemaa kuvaavia näkemyksiä (kts. Tuomi \& Sarajärvi 2009, 93). Käännekohtien yläteemoiksi muotoutuivat huostaanotto ja sen jälkeinen sijaishuoltoaika, itsenäistyminen, aikuisuus ja omillaan eläminen sekä vanhemmuus. Käännekohtien tematisoinnin jälkeen kokosin käännekohtiin liitettyjä kannattelevia tekijöitä sekä taakkatekijöitä, joiden koettiin vaikuttaneen heikentävästi silloiseen ja myöhempään elämänkulkuun.

Analyysiprosessin lopputuloksena syntyi neljä temaattista kategoriaa elämänkulun käännekohdista (kuvio 1). Käännekohtien sisällä on limittäisyyttä ja toistuvia asiayhteyksiä. Esimerkiksi huostaanoton käynnistämä kokemus ulkopuolisuudesta linkittyi niin koulumaailmaan, naapuripiiriin, työelämään kuin vanhemmuuteen kietoutuneena teemana. Osa puolestaan oli kokenut vanhemmuuden itsenäistymisen käännekohdan yhteydessä. Fokusryhmämetodissa yleisenä periaatteena on, että analyysin lähtökohtana on ryhmä eivätkä yksittäiset osallistujat (Stewart ym. 2007). Tulokset esitetään luokiteltuina teema-alueina tai pidemmälle kehiteltynä teoreettisena mallina (Mäntyranta \& Kaila 2008). Kuviossa kunkin käännekohdan yhteydessä on eritelty omat alakategoriat kannattelevista tekijöistä ja taakkatekijöistä. Käytän tulososiossa työpajojen, haastattelujen ja tarinoiden katkelmia. Työpajat, haastattelut ja kertomukset on numeroitu aikajärjestyksen mukaisesti.

\section{Tulokset}

Sijaishuollossa kasvaneet sanoittivat elämänkulun käännekohdiksi huostaanoton ja sijaishuoltoajan, siirtymän itsenäiseen elämään, omillaan elämisen sekä oman perheen perustamisen. Analyysin keskeiset tulokset esitetään kuviossa 1,

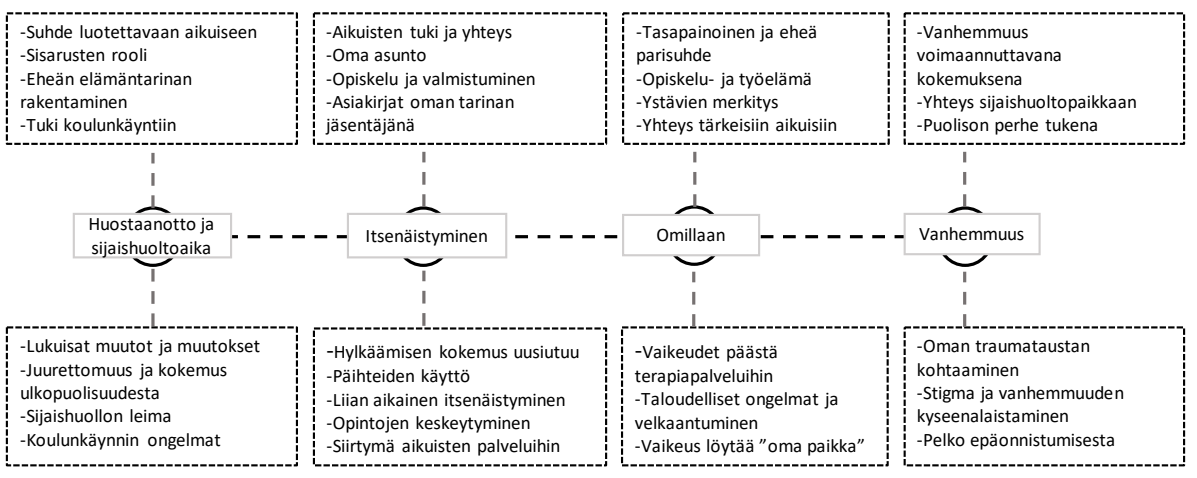

Kuvio 1. Elämänkulun käännekohdat ja niihin liittyvät kannattelevat tekijät ja taakkatekijät 
jossa ylemmät laatikot viittaavat kannatteleviin tekijöihin ja alemmat kuvaavat taakkatekijöitä käännekohdissa.

Huostaanotto ja sijaishuoltoaika elämänkulun käännekohtana

Huostaanottoa kuvattiin käännekohdaksi, jonka myötä käynnistyi polku sijaishuoltoaikaan. Osallistujat olivat kokeneet huostaanoton eri ikäisinä: suurin osa alle kouluikäisenä ja osa varhaisnuoruudessa. Valtaosa kuvasi huostaanottoa ja sijaishuoltoon sijoittamista pelastavaksi käännekohdaksi, joka oli tuottanut elämään positiivisen muutoksen, kuten turvallisuuden tunteen lisääntymisen.

"Mulle oli pelastus, että huostaanotto on tehty" Työpaja 4

"Lapsuuteni alkoi vasta kun minut huostaanotettiin ja sain olla minä. Sain turvaa ja rakkautta." Tarina 2

Useat kertoivat tiedostaneensa, että elämä syntymäperheessä olisi tuottanut täysin erilaisen elämänkulun. Teini-ikäisenä huostaanotetut toivat esiin kokemustaan siitä, että huostaanotto oli vaikuttanut negatiivisesti elämänkulkuun ja käännekohtaan liittyi kokemus siitä, ettei huostaanottopäätökseen voinut vaikuttaa.

Sijaishuoltoaika näyttäytyi useiden ihmisten ja elinympäristöjen kautta rakentuvana. Useat olivat kokeneet etääntymistä syntymäperheestään ja sukulaisistaan. Asuin- ja sijaishuoltopaikkojen muutokset, läheisten aikuisten vaihtuvuus ja ystävyyssuhteiden katkeamiset vaikuttivat osallistujien mukaan kykyyn asettua paikoilleen ja juurtua. Tunne juurettomuudesta vaikutti pitkälle aikuisuuteen ja saattoi johtaa esimerkiksi liikkuvaan elämäntyyliin. Esimerkiksi eräs osallistuja kuvasi asuneensa yli kolmessakymmenessä osoitteessa elämänsä aikana. Erityisen haitallisiksi koettiin sijaishuoltopaikkojen muutokset, jotka rapauttivat luottamusta ja pysyvyyttä.

”En ymmärrä käsitettä koti-ikävä. En mä osaa tehdä mistään paikasta kotia.’Työpaja 13

"Kenellä on täydellinen lapsuus? Ei kellään. Mutta se, että ollaanko me jotenkin herkempiä, kun meidät on lapsena huostaanotettu ja siirretty, et monet asiat ehkä tuntuu katkerimmilta ja vaikeemmilta. Varsinki, jos sun pitää piilotella noiden asioiden taustaa, niin ne nousee yliherkästi pintaan." Työpaja 20

Valtaosa toi esiin kokemusta ulkopuolisuudesta ja leimasta. Osalla oli tunne siitä, että omaa taustaa piti piilotella läpi elämän. Sijaishuollossa kasvaminen herätti tunteen erilaisuudesta ja ulkopuolisuudesta muihin verrattuna. Erilaisuuden ja ulkopuolisuuden kokemukset syventyivät vertaillessa elämää muiden lasten ja nuorten elämiin, joihin kuuluivat perhe, sukulaiset, ystävät ja pysyvät asuinpaikat. Leiman kokemus näyttäytyi moniulotteisena. Erilaisuutta ja ulkopuolisuutta luotiin eri ympäristöissä, kuten koulumaailmassa, jossa useat kertoivat tulleensa kiusatuksi.

"Pitää muistaa kehua lasta, kun on usein todella huono itsetunto ja lähtökohtanakin se, että siirrettiin koulusta toiseen ja olin aina uus oppilas siellä ryhmässä. Mua alettiin koulukiusaamaan ja sitten ei ikinä kehuttu. Siinä tuli sellanen, ettei enää usko 
itteensä ja alkaa uskoo niitä negatiivisia haukkuja” Työpaja 20

Kannattelevat tekijät liittyivät opettajien ja sijaishuoltopaikan aikuisten kannustukseen ja tukeen koulunkäynnissä. Huono suhde opettajaan ja oppimisen haasteet puolestaan johtivat useilla siihen, ettei koulunkäyntiin löytynyt motivaatiota. Kannattelevaksi tekijäksi mainittiin myös sisarusten sijoittaminen samaan sijaishuoltopaikkaan. Sisarusten läsnäolo toi turvaa monien muutosten keskellä. Positiivisena voimavarana koettiin samassa sijaishuoltopaikassa tai sijaisperheessä asuvat lapset ja nuoret, jotka muodostuivat perheenomaiseksi, tärkeäksi yhteisöksi.

"Mulla on 13 sisarusta ja äiti” Työpaja 13

Ihmissuhteiden näkökulmasta tärkeänä koettiin se, että sijaishuollon aikana syntyi edes yksi merkittäväksi koettu suhde aikuiseen. Merkittävät aikuissuhteet rakentuivat usein sijaisvanhempaan, sijaishuoltopaikassa toimivaan työntekijään (mm. omaohjaaja, johtaja), oman syntymäperheen jäseneen tai muuhun pitkäaikaiseen ihmissuhteeseen (esim. kummi tai muu sukulainen). Sijaishuoltoaikana koettiin tärkeäksi mahdollisuus rakentaa eheää eletyn elämän tarinaa ja omien juurien tuntemista. Osalle sijoituksen syyt olivat jääneet hämärän peittoon ja huostaanottoon kytkeytyi itsesyytösten ja epätietoisuuden tunteita. Lapsuusajan elämään liittyvä epätietoisuus saattoi synnyttää myöhemmin kokemuksen siitä, ettei ole kokonainen ihminen.

"Mä oon sulkenut lapsuusajan pois enkä muista muista hirveästi asioita. Tuntuu välillä, että itsestä puuttuu osa.” Työpaja 20
”Et mä en oo ikinä käynyt läpi mun elämänhistoriaa millään lailla, koska mua sijoitettiin paikasta paikkaan ja viimeisin sijaishuoltopaikka oli suljettu osasto X. -Niin ei oo tullut käytyä sitä läpi, ja sen takia se vähän kiinnostaa etenkin se lapsuusaika. Et mitä siellä on oikeesti tapahtunu." Työpaja 20

\section{Itsenäiseen elämään siirtyminen} käännekohtana

Itsenäisen elämän käännekohtaan sisältyi niin itsenäistymisen harjoittelu, sijaishuollon päättyminen kuin jälkihuoltoaika. Useiden osallistujien kokemuksissa yhdistyivät yksinäisyyden ja tarvitsevuuden sekä oman rauhan ja vapauden jännitteisyys.

"18.vuotta kun täyttää, niin vapautta on ollut äärimmäisen vähän ennen sitä. Kuus kuukautta heräilin iloissaan, että sai tehä mitä vaan." Työpaja 8

"Se on aika rankkaa, kun ollut aina paikassa useampi lapsi ja aikuinen koko ajan läsnä. Ei oo saanut opeteltua yksinoloa missään vaiheessa.” Työpaja 4

Käännekohta näyttäytyi myös vahvasti institutionaalisesti jäsentyneeltä. Useissa sijaishuoltopaikoissa itsenäistymisharjoittelu ajoittui 16-17 ikävuoteen ja omilleen muuttaminen viimeistään täysi-ikäistymisen myötä. Käännekohtaa varjosti kokemus hylkäämisen tunteesta ja pakotetusta itsenäistymisestä. Osa kertoi siitä, miten itsenäistyminen oli käynnistänyt negatiivisen kehän elämänkulussa tuen vähetessä radikaalisti.

"Toisaalta se on negatiivista, kun kerralla tulee vapaus. Sillon lähtee lapasesta." Työpaja 20 
"Muutto itsenäistymisasuntoon oli mulle negatiivinen käännekohta. Mä en ollut valmis 17-vuotiaana asumaan yksin. Kuvioihin tuli huumeet ja koulu jäi kesken.' Työpaja 4

Itsenäistymisen käännekohtaan kuului osalla runsas päihteiden käyttö ja rajattomalta tuntuva vapaus, joka korostui erityisesti tiukkoja rajoja sijaishuoltopaikassaan kokeneilla. Päihteet ja arjenhallinnan ongelmat johtivat osan kohdalla opintojen keskeytymiseen ja elämässä ajelehtimiseen.

Sijaishuollossa kasvaneiden itsenäistymisprosessia jäsensivät usein jälkihuollon palvelut. Jälkihuollon tuen loppuminen ja siirtymä aikuisten palveluihin koettiin jyrkkänä. Virallisen tuen päätyttyä useat kokivat, että tärkeiden ihmisten eteenpäin ohjaava tuki lakkasi täysin. Tuen loppumista kuvattiin kokemuksena siitä, että joutuu aikuistumaan "kertarysäyksellä". Kannattelevaksi tekijäksi itsenäistymisen ja poismuuton kynnyksellä koettiin se, että sijaishuoltopaikassa muodostuneet tärkeät aikuissuhteet jatkuivat. Useiden kohdalla täysi-ikäistyminen ja poismuutto kuitenkin katkaisivat nämä ihmissuhteet.

Itsenäistymisen käännekohdassa koettiin tärkeänä opiskelu ja tutkinnon saavuttaminen. Opintoihin hakeutumista ja opiskelupaikkavalintaa kuvattiin usein "arpomiseksi" ja oikean alan löytäminen kesti osallistujien mukaan pidempään.

"Ei ole helppoa päättää, mihin haluaa. Ensin amis meni päin $v^{\star \star \star}$ a ja tuntui, että on väärällä alalla. On vaikee päättää, mitä tekee tulevaisuudessa." Työpaja 15
Opiskelun kautta osallistujat kuvasivat päässeensä toteuttamaan unelmia ja omaa päätösvaltaa sekä tutustumaan uusiin ihmisiin. Tutkinnon saavuttamiseen kytkeytyi vahva tunne ylpeydestä, itsensä voittamisesta ja muille näyttämisestä.

Lastensuojelun asiakirjat saivat uudenlaista merkitystä itsenäistymisen käännekohdassa. Asiakirjoja luettiin vielä aikuisiällä ja niillä oli suuri merkitys oman lapsuus- ja nuoruusajan hahmottamisessa. Vaikka erilaiset dokumentit ja asiakirjat koettiin pääosin vastauksia antavina, niihin kytkeytyi myös mielikuvien ja asiasisällön välinen ristiriita. Asiasisältöjen koettiin usein keskittyvän ongelmiin ja epäkohtiin voimavarojen ja positiivisten piirteiden esille tuomisen sijaan.

"Niissä dokumenteissa kirjoitettiin ongelmanuoresta ja musta tuntui, ettei nähty sitä, että oon traumataustaa oireileva nuori." Työpaja 7

\section{Omillaan eläminen käännekohtana ja pärjäamisen koetinkivenä}

Omillaan elämisen käännekohta ajoittui jälkihuollon päättymisen jälkeiseen elämänvaiheeseen, jota useimmat osallistujat elivät parhaillaan. Omillaan elämiseen ja aikuisuuteen liittyi paljon ilon aiheita: oman kodin perustamista, vapautta, tulevaisuuden haaveita, parisuhteita ja pärjäämisen iloa.

"Mulle oli jäänyt sellanen olo, että et sä pärjää. Sit mä säästin aina toimeentulotuesta pienen osan pesämunaa pahan päivän varalle. -- Mä huomasin, et mitä ihmettä, mä pärjään ja pystyn itse tehdä päätökset." Työpaja 20 
Oman elämän rakentamista ja omillaan oloa tukeviksi tekijöiksi mainittiin "oman jutun" löytäminen, työ- tai opiskeluelämään kiinnittyminen sekä ystävien ja seurustelukumppanin antama tuki. Tärkeäksi tekijäksi nähtiin yhteydenpidon jatkuminen tärkeään ja luotettavaan aikuiseen. Voimavarat linkittyivät moninaisin tavoin ihmissuhteiden rooliin: ystäviin, tuttuihin aikuisiin ja kumppaneihin. Sijaishuollosta aikuistuneet toivat esiin pitävänsä yhteyttä myös samassa sijaishuoltopaikassa kasvaneisiin nuoriin. Yhteydenpidon ja vuorovaikutussuhteiden jatkuvuus koettiin tärkeäksi erityisesti siksi, että kyseisiä ihmisiä yhdisti samanlainen kokemustausta.

Tärkeäksi tukea antavaksi elementiksi koettiin parisuhteen muodostaminen. Puolison löytymisellä ja tasapainoisilla parisuhdekokemuksilla oli ollut suuri merkitys elämänhallinnan, itsetunnon ja turvallisuudentunteen kannalta. Parisuhteen nähtiin tuoneen elämään onnellisuutta, tukea ja voimavaroja. Parisuhde mahdollisti itsestä oppimisen ja ihmisenä kasvamisen.

"Normaaleilla on porukat tukemassa ja neuvomassa, mut sijoitetulla ei välttämättä oo ketään. Jos on mennyt välit (sijaishuoltopaikkaan), monella on tullut yksin jääminen. ”Тyöpaja 15

"Kun jälkihuolto loppuu, tulee tunne, ettei ole enää ketään.” Työpaja 15

Omillaan elämisen käännekohtaan liitettiin myös kokemuksia yksinäisyydestä ja tuen puutteesta. Keskusteluissa vertailua tehtiin usein syntymäperheestä itsenäistyvien ja sijoitettujen nuorten tilanteiden välillä. Käännekohtaan liit- tyi kokemus aikuispalvelujen vaikeasta saatavuudesta. Tarvittavia palveluja jouduttiin usein jonottamaan ja omaa taustaa ei päässyt työstämään terapiaan silloin, kun siihen olisi ollut oikea hetki. Usealle oman taustan käsittelemisen tarve nousi vasta jälkihuoltoiän ylittämisen jälkeen. Omillaan elämistä varjostivat taloudelliset vaikeudet, joihin kytkeytyivät pikavippien kasaantuminen sekä velkaantumisen tuottama turvattomuus. Oman talouden hallinta oli usein kadoksissa ja useat joutuivat vastaamaan pikavippien ottamiseen liittyvistä pitkäaikaisista ongelmista.

\section{Vanhemmuus käännekohtana}

Kaikki osallistujat eivät olleet kokeneet vanhemmuutta, mutta työpajoissa siitä muodostui tärkeä keskusteluteema, jota osallistujat reflektoivat myös mahdollisen tulevan vanhemmuuden näkökulmasta. Lapsen saamisen ja oman perheen perustamisen käännekohta herätti reflektointia omiin vanhempiin, elettyyn lapsuuteen sekä vanhemmuuden unelmiin ja ihanteisiin liittyen. Enemmistö vanhemmaksi tulleista osallistujista $(n=17)$ oli saanut ensimmäisen lapsen nuorella iällä. Lapsen saaminen oli osalle suunnittelematon yllätys ja osalle hartaasti odotettu tapahtuma. Yhteisenä tekijänä näyttäytyi kokemus siitä, että vanhemmuus antoi elämälle uudenlaista merkitystä ja toimi mahdollisuutena muutokseen.

"Se tuntui tosi hyvältä ja olin onnellinen. Olin silloin 20-vuotias. Mun päässä oli ajatus, että nyt tästä elämästä ehkä tuleekin jotain. Muistan, että ennen ajattelin, että jos 30-vuotiaaksi elää, niin se on jo hyvä juttu. Raskaus oli pelastus siinä tilanteessa.” Haastattelu 3 
"Jos itsellä on rikkinäinen tausta, sä haluut tarjota lapselle kaiken parhaimman." Työpaja 8

Sijaishuollossa kasvamisen ja oman perheen rikkinäisyyden koettiin vaikuttaneen käännekohtaan niin, että ydinperheen ideaali ja ehjän perheen unelma olivat tärkeitä päämääriä. Osallistujien ajatuksissa oli vahva halu tarjota omalle lapselle parempi lapsuus. Vaikka oma rikkinäiseksi koettu perhetausta antoi voimaa toisin toimiselle, ehjän perheen unelma saattoi kääntyä myös negatiiviseksi tavoitteeksi. Esimerkiksi osa pysyi pahoinvointia tuottavassa parisuhteessa siksi, että ehjän perheen unelman ei haluttu särkyvän. Kahdella vanhemmalla oli kokemus erosta ensimmäisen lapsen syntymän aikaan. Eroa kuvattiin oikeaksi ratkaisuksi, mutta siihen kytkeytyi suurta surua ja unelmien särkymistä.

"Mulla oli pienestä pitäen unelma tulla äidiksi ja saada oma perhe. Mä tulin äidiks, kun olin 21 ja menin naimisiin lapsen isän kanssa. Mulle oli tärkeetä, että perheessä on sama sukunimi. Vauvavaihe oli kuitenki niin raskas, se vei voimat ja johti eroon. Ero oli oikee ratkaisu, mut vaikeeta oli se, kun on koko elämän tavoitellut perhettä ja sitten se unelma särkyy. Sitä sokeesti uskoo perheeseen, koska sitä ei oo koskaan ollut." Työpaja 8

Vanhemmuutta varjosti usein pelko oman lapsen huostaanotosta ja huoli siitä, että tulee toistaneeksi samoja virheitä kuin omat vanhemmat. Tärkeäksi voimavaraksi koettiin ihmiset, jotka olivat olleet pitkään osallisina elämässä (mm. sijaisvanhempi, ohjaaja), ja jotka olivat korvaamassa poissaolevia isovanhempia sekä opastamassa kasvatuksessa ja perhe-elämässä eteenpäin. Oman vanhemmuuden myötä osallistujat kertoivat kokeneensa myös syvää surua siitä, että yhteydet omiin vanhempiin ja sukuun olivat kuihtuneet. Osan kohdalla tätä puutetta paikkasivat puolison vanhemmat.

"Tunteet äidiksi tulemisessa olivat ristiriitaiset. Ajattelin silloin ja vieläkin nykypäivänä, että en koskaan halua tehdä niitä samoja virheitä kuin äitini teki. ” Tarina 2

Käännekohta pakotti kohtaamaan oman menneisyyden uudestaan nostaen pintaan traumaattisia kokemuksia omasta lapsuusajasta. Vanhemmaksi tulleet osallistujat kuvasivat, miten raskausajan ja oman lapsen tietyn ikävaiheen myötä mieleen oli noussut takautuvia muistikuvia omista turvattomuuden ja pelon kokemuksista, vanhempien päihteidenkäytöstä tai seksuaalisesta hyväksikäytöstä. Vanhemmuuteen liittyvien tunteiden käsittelemiseen toivottiin enemmän tukea palvelujen osalta.

Osalla oli kokemus ympäristön tuottamasta tuplastigmasta nuoren iän ja sijaishuoltotaustan takia. Sijaishuollossa kasvaminen ja siihen liittyvä elämänhistoria muotoutuivat usein vanhemmuuden taitoja kyseenalaistaviksi ulottuvuuksiksi erityisesti lapsi- ja perhepalveluissa.

"Mulle sanottiin, et jos et mene ensikotiin, niin lapsi otetaan pois. Kaikesta tehtiin negatiivista.” Työpaja 5

"Niin se (neuvolatyöntekijä) sano, että mä en voi tietää mitä on perhe-elämä, kun mä en oo perheessä kasvanut. Et se vähän niin kuin sano, ettei vaihtoehtoja ole muuta kuin antaa se lapsi pois." Haastattelu 2 
Vaikka vanhemmuuden käännekohta koettiin mullistavaksi ja positiiviseksi tapahtumaksi, sijaishuoltotausta vaikutti ympäristön suhtautumiseen. Negatiivinen suhtautuminen, stigma, kyseenalaistaminen ja paine osoittaa olevansa hyvä vanhempi olivat vahvasti läsnä käännekohtakokemuksissa.

\section{YHTEENVETO JA JOHTOPÄÄTÖKSET}

Tarkastelin artikkelissa sijaishuollossa kasvaneiden käännekohtakokemuksia. Käännekohdat eivät määrity mustavalkoisesti positiivisiksi tai negatiivisiksi, vaan niiden sisään mahtuu moninaisia, ristiriitaisiakin tunteita. Tutkimus tarjoaa uutta tietoa lastensuojelujärjestelmän roolista käännekohtaprosesseissa. Käännekohtien analyysi nostaa esiin tärkeitä tekijöitä, jotka vaikuttavat sijaishuollossa kasvaneiden kokemuksiin hyvinvoinnista sekä osoittavat kehityskohtia, jotka on hyvä huomioida lastensuojelun kentällä.

Aiempien tutkimusten tavoin käännekohtien merkitys linkittyi ihmis- ja perhesuhteiden, työ- ja opiskeluelämän sekä sosiaalisten ympäristöjen muutoskohtiin. Normatiiviset käännekohtatapahtumat, kuten omilleen muuttaminen ja vanhemmuus, nousivat esille kokemuksissa. Käännekohdissa tehtiin usein vertailua "normaaliin lapsuuteen", jonka nähtiin pitävän sisällään syntymäperheessä asumisen, ihmissuhteiden pysyvyyden ja vahvemman tuen roolin elämän eri vaiheissa. Vertailu ja rajanteko tuottivat ulkopuolisuuden ja leiman kokemusta, joka saattoi kulkea varjona läpi elämänkulun. Toisaalta samanlaisen kokemustaustan omaavien kanssa koettiin vahvaa yhteisöllisyyttä.
Vertaissuhteiden merkitys nousi esille myös Rogersin (2017) tutkimuksessa, jonka mukaan suhteet sijaishuoltopaikan muihin nuoriin toimivat sosiaalisen pääoman kartuttajina ja vähentävät kokemusta stigmasta.

Gilliganin (2009) mallintamat käännekohdan ulottuvuudet esiintyivät moniulotteisesti käännekohtakokemuksissa. Esimerkiksi sijaishuoltoaika näyttäytyi valtaosalle käänteentekevänä tilaisuutena, jonka kautta mahdollistui turvallisempi lapsuus ja nuoruus. Valmiutta ja toimijuutta vahvistivat kokemukset siitä, että huostaanotto oli oikea ratkaisu. Kannattelevan kontekstin näkökulmasta merkittäviksi tekijöiksi muodostuivat kannustavat, jatkuvat ihmissuhteet ja oman elämänhistorian tuntemus. Ulottuvuudet toistuivat kussakin käännekohdassa. Itsenäistyminen avasi tilaisuuden kokeilla omia siipiä, toimijuuden kokemusta vahvisti tutkinnon saavuttaminen sekä työpaikka ja omillaan pärjäämisen voimaannuttavat kokemukset. Kannattelevana kontekstina toimivat merkittävien ihmissuhteiden (ystävät, parisuhde, tärkeät aikuiset) läsnäolo. Kyseiset käännekohtien ulottuvuudet eivät kuitenkaan liittyneet vain positiivisiksi koettuihin käännekohtiin. Käännekohdasta vaikutti muodostuvan negatiivinen erityisesti silloin, kun siihen liittyi vähäinen oman toimijuuden kokemus. Tällaisia kokemuksia nousi esiin esimerkiksi tilanteissa, joissa huostaanottopäätökseen ei koettu olleen vaikutusmahdollisuuksia tai itsenäistymään jouduttiin, vaikka siihen ei koettu olevan valmis.Vanhemmaksi tullessa puolestaan negatiivista kokemusta lisäsi ympäristön heikko kannattelevuus. 
Tulosten mukaan sijaishuolto tuo mukanaan erityispiirteitä ja institutionaalisia rakenteita käännekohtakokemuksiin. Esimerkiksi itsenäistymisen elämänvaiheessa suuressa roolissa oli täysi-ikäistymisen virstanpylväs, joka asetti osan itsenäistymispakon eteen todellisia valmiuksia huomioimatta. Kankea näkemys siitä, että tietyn iän saavuttaminen käynnistää siirtymisen riippuvaisuudesta itsenäisyyteen ei heijasta todellisuutta. Poismuuttamisen käännekohdassa nuorten on käsiteltävä oman menneisyyden sidonnaisuudet ja suunnattava samanaikaisesti kohti tulevaa. Sijaishuollosta aikuistuvilla on todettu olevan suurempi riski kokea vaikeuksia aikuisuuteen siirtymisessä (Dixon 2008). Itsenäistymiseen on myös lyhyempi aika ja se tapahtuu nuoremmalla iällä saman ikäluokan vertaisiin verrattuna (Höjer \& Sjöblom 2014). Useat tutkimukset ottavat myös kantaa siihen, että tuki itsenäistymisessä ja varhaisaikuisuudessa on riittämätöntä (Höjer \& Sjöblom 2010; SulimaniAidan 2014; Fransson \& Storø 2011; Reinikainen 2009, 191) ja mielenterveyspalveluja ei saa tarpeesta huolimatta (Heino ym. 2016; Puustinen-Korhonen 2018).

On tärkeää, että sijaishuoltopaikasta poismuuttavalle nuorelle jäisi elämään tukea antavia aikuisia. Lastensuojelutoimien käynnistämät institutionaaliset rakenteet näyttävät vaikuttavan oleellisesti ihmissuhteiden ylläpidon mahdollisuuksiin. Osalla yhteydet syntymäperheeseen ja sukuun katkesivat ja kuihtuivat huostaanoton käännekohdan myötä. Lisäksi tärkeäksi koetut aikuissuhteet harvoin jatkuivat nuorten elämässä kannattelevina suhteina sijaishuollosta muuttamisen jälkeen.
Nuorelle saattaa syntyä kokemus siitä, ettei hän voi vaikuttaa tai valita asioiden ja ihmissuhteiden ylläpitämisen väliltä. Sijaishuollossa kasvavia lapsia ja nuoria ei rohkaista tai ohjata jatkamaan syntynyttä yhteyttä tai käsittelemään suhteiden päättymistä. Näillä kokemuksilla voi olla merkittäviä vaikutuksia oman toimijuuden muodostumiseen. (Pryce ym. 2017.) Käännekohdat voivat muokata toimijuuden tuntoa. Toimijuuden tunto tai sen puute voivat vaikuttaa yksilön suhtautumiseen elämään käännekohtien yhteydessä (Juntunen 2020).

Käännekohdat osoittavat merkittäviä paikkoja, joihin tulee kiinnittää vahvemmin huomiota sijaishuollossa kasvavien ja itsenäistyvien tukemisessa. Itsenäisyyttä, aikuisuutta ja omaa vanhemmuutta kannattelevien tekijöiden näkökulmasta avainasemassa ovat ihmissuhteiden jatkuvuuden turvaaminen, koherentin ja eheän elämäntarinan jäsentäminen, riittävän pitkälle jatkuva tuki itsenäistymisessä ja aikuisuuteen siirtymisessä sekä kannustus vanhemmuuden vaiheessa. Sijaishuoltoaikana olisi tärkeää tarjota väylä käydä avointa keskustelua elämänhistorian merkityksestä eheän omaelämäkerrallisen tarinan luomiseksi. Eheän elämäntarinan kokemuksella on tärkeä merkitys yksilön hyvinvoinnille (Habermas \& Köber 2015; Merril ym. 2016). Todenmukainen kuva huostaanottoon johtaneista syistä sekä ymmärrys omien vanhempien toiminnasta ja oman elämänhistorian merkityksestä korostuivat erityisesti itsenäistymisen ja oman perheen perustamisen käännekohdissa. Vanhemmuuteen liittyvä vahva toisin toimimisen tahto on tullut esiin useissa sijaishuollossa kasvaneiden vanhemmuutta käsittelevissä tutkimuksissa 
(mm. Rolfe 2008; Pryce \& Samuels 2010; Aparicio ym. 2015). Oma perhehistoria toimii vanhemmuuden rakentamisen peilinä. Sijaishuollossa kasvaneille tämä heijastaa erityisesti tapoja ja asioita, joita he eivät halua itse toistaa vanhemmuudessaan. Vanhemmuuden koetinkiveksi saattaa muodostua se, ettei elämässä ole kannattelevia aikuisia tukemassa. Sijaishuollossa kasvaneiden vanhemmuuden kokemukset nostavat esiin myös kysymyksen, miten palveluissa ja niissä tapahtuvissa kohtaamisissa voitaisiin huomioida haavoittavia lapsuuden kokemuksia elämänhistoriassaan mukanaan kantavat vanhemmat ketään leimaamatta.

\section{VIITE}

1 SOS-Lapsikylän Ylitse-projektin (20162019) tavoitteena on kehittää palveluja ja menetelmiä lastensuojelun ylisukupolvisten asiakkuuksien ehkäisemiseksi yhdessä kokemusasiantuntijoiden ja ammattilaisten kanssa.

\section{KiITOKSET}

Suuret kiitokset Ylitse-projektin toimintaan osallistuneille elämäntarinoiden rohkeasta jakamisesta. Kiitos myös projektipäällikkö Oskari Savisalolle työkumppanuudesta ja aineiston hankintaan osallistumisesta. Lisäksi kiitos kuuluu väitöskirjaohjaajille Tarja Pösölle ja Tarja Heinolle artikkelin kommentoinnista.

\section{KirJallisuUs}

Acocella, Ivana (2012) The focus groups in social research: advantages and disadvantages. Quality \& Quantity, 46 (4),
1125-1136. https://doi.org/10.1007/ s11135-011-9600-4

Aparicio, Elizabeth \& Pecukonis, Edwars \& O'Neale, Shalita (2015) “The love that I was missing": Exploring the lived experience of motherhood among teen mothers in foster care. Children and Youth Services Review 51, 44-54. https://doi. org/10.1016/j.childyouth.2015.02.002

Brady, Eevan \& Gilligan, Robbie (2018) The life course perspective: An integrative research paradigm for examining the educational experiences of adult care leavers? Children and Youth Services Review 87, 69-77. https://doi. org/10.1016/j.childyouth.2018.02.019

Corman, Hope \& Noonan, Kelly \& Reichman, Nancy \& Schwartz-Soicher, Ofira (2011) Life shocks and crime: A test of the "turning point" hypothesis. Demography 48 (3), 1177-1202. https://doi. org/10.1007/s13524-011-0042-3

Dixon, Jo (2008) Young people leaving care: Health well-being and outcomes. Child and Family Social Work 13, $207-$ 217. https://doi.org/10.1111/j.13652206.2007.00538.x

Drapeau, Sylvie \& Saint-Jacques, MarieChristine \& Lépine, Rachel \& Bégin, Gilles \& Bernard, Martine (2007) Processes that contribute to resilience among youth in foster care. Journal of adolescence 30 (6), 977-999. https://doi. org/10.1016/j.adolescence.2007.01.005

Dun, Tim (2010) Turning points in parentgrandparent relationships during the start of a new generation. Journal of $\mathrm{Fa}-$ mily Communication 10 (3), 194-210. https://doi.org/10.1080/15267431.201 0.489218

Elder, Glen (1994) Time, human agency, and social change: Perspectives on the life course. Social psychology quarterly 57 (1), 4-15. https://doi.org/10.2307/2786971

Enz, Karalyn \& Talarico, Jennifer M. (2016) Forks in the road: Memories of turning points and transitions. Applied Cognitive Psychology 30 (2), 188-195. https://doi. org/10.1002/acp.3176

Fransson, Elisabetf \& Storø, Jan (2011) Dealing with the past in the transition from care. A post-structural analysis of young people's accounts. Children and Youth Services Review 33 (12), 2519- 
2525. https://doi.org/10.1016/j.childyouth.2011.08.021

Gilligan, Robbie (2009) Positive Turning Points in the Dynamics of Change over the Life Course. Teoksessa Jay A. Mancini \& Karen A. Roberto (toim.) Pathways of human development: Explorations of change. United Kingdom: Lexington Books, 15-34.

Habermas, Tilmann \& Köber, Christin (2015) Autobiographical reasoning in life narratives buffers the effect of biographical disruptions on the sense of self-continuity. Memory 23 (5), 664-674. https:// doi.org/10.1080/09658211.2014.9208 85

Heino, Tarja \& Hyry, Sylvia \& Ikäheimo, Salla \& Kuronen, Mikko \& Rajala, Rika (2016) Lasten kodin ulkopuolelle sijoittamisen syyt, taustat, palvelut ja kustannukset: HuosTa-hankkeen (2014-2015) päätulokset. Terveyden ja hyvinvoinnin laitos, raportti 3/2016.

Hurren, Emily \& Stewart, Anna \& Dennison, Susan (2017) Transitions and turning points revisited: A replication to explore child maltreatment and youth offending links within and across Australian cohorts. Child Abuse \& Neglect 65, 24-36. https://doi.org/10.1016/j. chiabu.2017.01.002

Hutchison, Elizabeth (2005) The life course perspective: A promising approach for bridging the micro and macro worlds for social workers. Families in Society 86 (1), 143-152. https://doi. org/10.1606/1044-3894.1886

Hämäläinen, Kati \& Pirskanen, Henna \& Rautio, Susanna (2014) Sensitiiviset perheaiheet haastattelututkimuksessa Eettiset haasteet, perhesalaisuudet ja intervention mahdollisuus. Janus 22 (1), 53-68.

Hänninen, Vilma (2002) Sisäinen tarina, elämä ja muutos. 4. painos. Acta Universitatis Tamperensis 696. Tampere: Tampere University Press.

Höjer, Ingrid \& Sjöblom, Yvonne (2010) Young people leaving care in Sweden. Child \& Family Social Work 15 (1), 118127. https://doi.org/10.1111/j.13652206.2009.00661.x

Höjer, Ingrid \& Sjöblom, Yvonne (2014) What Makes a Difference? Turning
Points for Young People in the Process of Leaving Placements in Public Care. Social Work \& Society 12 (1).

Juntunen, Anna (2020) Nuoret ja elävä toimijuuden tunto elämänkulun käännekohdissa. Janus 28 (1), 20-41. https:// doi.org/10.30668/janus.70093

Kekkonen, Merja (2005) Vanhemmuutta etsimässä ja tukemassa. Lapsiperheiden peruspalveluiden kehittäminen. Raportteja 281/2004. Helsinki: Stakes.

Laitinen, Merja \& Uusitalo, Tuula (2007) Sensitiivisen haastattelututkimuksen eettiset haasteet. Janus 15 (4), 316-332.

Manoogian, Margaret \& Vandenbroeke, Juliana \& Ringering, Amy \& Toray, Tamina \& Cooley, Eric (2018) Emerging Adults' Experiences of Grandparent Death. OMEGA-Journal of Death and Dying 76 (4), 351-372. https://doi. org/10.1177/0030222817693140

McLean, Kate \& Pratt, Michael (2006) Life's little (and big) lessons: Identity statuses and meaning-making in the turning point narratives of emerging adults. Developmental Psychology 42, 714722. https://doi.org/10.1037/00121649.42.4.714

Melde, Chris \& Esbensen, Finn-Aage (2011) Gang Membership as a Turning Point in the Life Course. Criminology 49 (2), 513-552. https://doi. org/10.1111/j.1745-9125.2011.00227.x

Merrill, Natalie \& Waters, Theodore \& Fivush, Robyn (2016) Connecting the self to traumatic and positive events: Links to identity and well-being. Memory 24 (10), 1321-1328. https://doi.org/10.108 0/09658211.2015.1104358

Montemurro, Beth (2014) Getting married, breaking up, and making up for lost time: Relationship transitions as turning points in women's sexuality. Journal of Contemporary Ethnography 43 (1), 64-93. https://doi. org/10.1177/0891241613494808

Murray, Suellen \& Goddard, Jim (2014) Life after growing up in care: Informing policy and practice through research. Australian Social Work 67 (1), 102-117. https://doi.org/10.1080/0312 407X.2013.868010

Mäntyranta, Taina \& Kaila, Minna (2008) Fokusryhmähaastattelu laadullisen 
tutkimuksen menetelmänä lääketieteessä. Lääketieteellinen aikakauskirja Duodecim 124 (13), 1507-1513.

Nousiainen, Kirsi (2016) Ylisukupolvisten ilmiöiden näkyväksi tekeminen, ymmärtäminen ja purkaminen narratiivisella työskentelyllä sosiaalityössä. Teoksessa Kirsi Nousiainen, Päivi Petrelius \& Laura Yliruka (toim.) Puheista tekoihin! Ylisukupolvisten ongelmien ehkäiseminen lastensuojelussa ja perhe- ja sosiaalipalveluissa. Terveyden ja hyvinvoinnin laitos. Työpapereita 20, 71-81.

Okpych, Nathanael \& Feng, Huiling \& Park, Keunhye \& Torres-García, Adrianna \& Courtney, Mark (2018) Living Situations and Social Support in the Era of Extended Foster Care: A View from the US. Longitudinal and Life Course Studies 9 (1), 6-29. https://doi. org/10.14301/llcs.v9i1.449

Petroff, Alisa (2016) Turning points and transitions in the migratory trajectories of skilled Romanian immigrants in Spain. European Societies 18 (5), 438459. https://doi.org/10.1080/14616696 .2016 .1139158

Pillemer, David \& Desrochers, Amy \& Ebanks, Caroline (1998) Remembering the past in the present:Verb tense shifts in autobiographical memory narratives. Autobiographical memory: Theoretical and applied perspectives, 145-162. https:// doi.org/10.4324/9781315784250-9

Pryce, Julia \& Napolitano, Laura \& Samuels, Gina (2017) Transition to adulthood of former foster youth: Multilevel challenges to the help-seeking process. Emerging Adulthood 5 (5), 311-321. https://doi. org $/ 10.1177 / 2167696816685231$

Pösö, Tarja (2008) Kiistanalaiset perhesuhteet ja tutkimisen moraali. Teoksessa Eija Sevón \& Marianne Notko (toim.) Perhesuhteet puntarissa. Helsinki: Palmenia, 93-107.

Reinikainen, Sarianna (2009) Nuorisokodista maailmalle. Kokemuksia nuorisokodissa elämisestä ja aikuisiässä selviytymisestä. Kasvatustieteen laitoksen tutkimuksia. Helsinki: Helsingin yliopisto.

Reynolds, John R. \& Turner, Jay (2008) Major life events: Their personal meaning, resolution, and mental health sig- nificance. Journal of Health and Social Behavior 49 (2), 223-237. https://doi. org/10.1177/002214650804900208

Rogers, Justin (2016) 'Different'and 'Devalued': Managing the Stigma of FosterCare with the Benefit of Peer Support. British Journal of Social Work 47 (4) 1078-1093. https://doi.org/10.1093/ bjsw/bcw063

Rolfe, Alison (2008) 'You've got to grow up when you've got a kid': Marginalized young women's accounts of motherhood. Journal of Community \& Applied Social Psychology 18 (4), 299-314. https://doi. org/10.1002/casp.925

Rutter, Michael (1996) Transitions and turning points in developmental psychopathology: As applied to the age span between childhood and mid-adulthood. International Journal of Behavioral Development 19 (3), 603-626. https://doi. org/10.1177/016502549601900309

Rönkä, Anna \& Oravala, Sanna \& Pulkkinen, Lea (2003) Turning points in adults' lives: The effects of gender and the amount of choice. Journal of Adult Development 10 (3), 203-215. https:// doi.org/10.1023/A:1023418414709

Shanahan, Michael J. (2000) Pathways to adulthood in changing societies:Variability and mechanisms in life course perspective. Annual Review of Sociology 26 (1), 667-692. https://doi.org/10.1146/ annurev.soc.26.1.667

Stewart, Anna \& Livingston, Michael \& Dennison, Susan (2008) Transitions and turning points: examining the links between child maltreatment and juvenile offending. Child Abuse and Neglect 31 (1), 51-66. https://doi.org/10.1016/j. chiabu.2007.04.011

Stewart, David \& Shamdasani, Prenn \& Rook, Dennis (2007) The focus group moderator. Focus Groups, 69-89. https:// doi.org/10.4135/9781412991841.d29

Tavernier, Royette \& Willoughby, Teena (2012). Adolescent turning points: The association between meaning-making and psychological well-being. Developmental Psychology 48 (4), 1058-1068. https://doi.org/10.1037/a0026326

Teruya, Cheryl \& Hser, Yih-Ing (2010) Turning points in the life course: current findings and future directions in 
drug use research. Current Drug Abuse Reviews 3 (3), 189-195. https://doi. org/10.2174/1874473711003030189

Tuomi, Jouni \& Sarajärvi, Anneli (2009) Laadullinen tutkimus ja sisällönanalyysi. 5. uudistettu painos. Helsinki: Tammi.

Valtonen, Anu (2005) Ryhmäkeskustelut -millainen metodi? Teoksessa Johanna Ruusuvuori \& Liisa Tiittula (toim.) Haastattelu: tutkimus, tilanteet ja vuorovaikutus. Tampere:Vastapaino.

Vesely, Colleen \& Goodman, Rachael \& Scurlock, Shannon (2014) Turning points and transitions: The role of family in women's immigration experiences. International Journal of Child, Youth \& Family Studies 5 (2), 308. https://doi. org/10.18357/ijcyfs.veselyc.522014
Wethington, Elaine (2002) The relationship of turning points at work to perceptions of psychological growth and change. Advances in Life Course Research 7, 111131. https://doi.org/10.1016/S10402608(02)80032-6

White, Kevin R \& Qi Wu (2014) Application of the life course perspective in child welfare research. Children andYouth Services Review 46, 146-154. https://doi. org/10.1016/j.childyouth.2014.08.018

Zimbrick-Rogers, Charles G. \& Ginsburg, Kenneth \& Hill, Cordella \& Fegley, Suzanne \& Ravitch, Sharon \& Ford, Carol A. (2017) Parenthood and Motivation to Change in Homeless Older Adolescents. Journal of Poverty 21 (3), 227-246. https://doi.org/10.1080/10875549.201 6.1141387 